Syntax Literate: Jurnal Ilmiah Indonesia p-ISSN: 2541-0849

e-ISSN: 2548-1398

Vol. 7, No. 1, Januari 2022

\title{
FEMINISME DAN KESETARAAN GENDER DALAM KAJIAN ISLAM KONTEMPORER
}

\section{Dzakiyyah Fauziyah Rif'at, Nurwahidin}

Universitas Indonesia (UI) Depok Jawa Barat, Indonesia

Email: dzakiyyah.fauziyah@ui.ac.id,nurwahidin@ui.ac.id

\begin{abstract}
Abstrak
Feminisme yang lahir dari ketimpangan sosial dan budaya patriarki di Barat pada abad 20 memberikan pengaruh pada pemikiran Islam kontemporer. Dalam kajian Islam kontemporer, pemikiran feminis Islami mengkritik ayat-ayat Al-Qur'an tentang perempuan, hadits misogini dan hukum-hukum Islam yang dianggap tidak adil dan relevan bagi perempuan. Oleh karena itu perlu adanya diskursus lebih lanjut untuk meluruskan kesalahan berpikir dalam hal tersebut. Penelitian ini bertujuan untuk mengetahui bagaimana kajian Islam kontemporer melihat kritik feminis Islami dan bagaimana membuktikan tuduhan-tuduhan yang dilayangkan oleh mereka tidaklah benar. Metode yang digunakan dalam penelitian ini adalah metode kualitatif deskriptif dengan paradigma kritis. Penelitian ini mencoba menggambarkan fenomena, gejala, fakta dan realitas sosial dan dibahas secara mendalam sehingga memberikan pemahaman baru yang melawan pemahaman sebelumnya. Adapun data yang digunakan dalam penelitian ini bersumber dari berbagai literatur seperti buku dan jurnal, sehingga penelitian ini merupakan penelitian kualitatif dengan studi pustaka. Hasil dari penelitian ini menunjukkan bahwa pemikiran feminis Islami yang mengkritik Al-Qur'an, hadits dan hukum Islam merupakan pengaruh dari feminisme yang berkembang di Barat. Hal ini tidak terlepas dari budaya patriarki dan ketimpangan sosial. Kritik mereka mengenai konsep perempuan dalam Islam merupakan kesalahan berpikir yang hanya melihat Islam secara kontekstual. Hal ini menyebabkan semangat emansipasi yang mendasari pemikiran tersebut berupaya merekonstruksi hasil dan produk ulama klasik Islam.
\end{abstract}

Kata Kunci: feminisme; feminis islami; misogini; patriarki

\section{Abstract}

Feminism that was born from social inequality and patriarchal culture in the West in the 20th century gave an influence on contemporary Islamic thought. In contemporary Islamic studies, Islamic feminist thought criticizes the verses of the Qur'an about women, misogyny hadiths and Islamic laws which are considered unfair and relevant to women. Therefore, there is a need for further discussion to correct the wrong thinking in this regard. This study aims to find out how contemporary Islamic studies view Islamic feminist criticism and how to prove the accusations made by them are not true. The method used in this study is a descriptive qualitative method with a critical paradigm. This study tries to describe phenomena, symptoms, facts and social realities and is discussed in depth so as to

$\begin{array}{ll}\text { How to cite: } & \text { Rif'at. D. F \& Nurwahidin (2022) Feminisme dan Kesetaraan Gender dalam Kajian Islam Kontemporer. Syntax } \\ & \text { Literate: Jurnal Ilmiah Indonesia, 7(1). http://dx.doi.org/10.36418/ Syntax-Literate.v7i1.6038 } \\ \text { E-ISSN: } & \text { 2548-1398 } \\ \text { Published by: } & \text { Ridwan Institute }\end{array}$


provide a new understanding that contradicts previous understandings. The data used in this research comes from various literatures such as books and journals, so this research is qualitative research with literature study. The results of this study indicate that Islamic feminist thought that criticizes the Qur'an, hadith and Islamic law is the influence of feminism that has developed in the West. This is inseparable from the patriarchal culture and social inequality. Their criticism of the concept of women in Islam is a mistake in thinking that only sees Islam contextually. This causes the spirit of emancipation that underlies this thought to try to reconstruct the results and products of classical Islamic scholars.

Keywords: feminism; islamic feminists; misogyny; patriarchy

Received: 2021-12-20; Accepted: 2022-01-05; Published: 2022-01-15

\section{Pendahuluan}

Gerakan feminisme yang muncul di pada abad 19 dan berkembang pesat di abad 20 akibat adanya ketimpangan gender dalam tatanan sosial dan politik memunculkan pemikiran-pemikiran kontemporer yang mengedepankan hak-hak wanita dalam berbagai aspek kehidupan. Hal tersebut tak lepas dari keadaan kultur sosial pada masa lampau yang menganggap wanita sebagai pihak pembawa sial bahkan dianggap penyihir dan lebih baik dimusnahkan. Melengkapi gerakan feminisme, muncullah isu kesetaraan gender yang semakin menyalakan api semangat feminisme. Maka gerakan feminisme dan kesetaraan gender mencoba untuk menstabilkan peran laki-laki dan perempuan dalam berbagai ranah kehidupan bahkan membalikkan keadaan agar perempuan tidak lagi dianggap sebelah mata (Adian Husaini, 2020).

Tidak hanya di Barat, isu feminisme dan gender ini juga telah masuk ke dalam kajian Islam kontemporer yang memunculkan pemikiran-pemikiran yang menkritisi AlQur'an, hadits dan hukum-hukum Islam yang dianggap tidak adil dan relevan bagi kaum wanita. Bahkan mulai adanya wacana Islam feminis berlandaskan ayat-ayat AlQur'an yang ditafsirkan secara hermeneutik. Salah satu buktiny adalah buku yang diterbitkan oleh Pusat Studi Jender IAIN Walisongo Semarang tahun 2002 yang berjudul Pemahaman Islam dan Tantangan Keadilan Jender membahas mengenai berbagai praktek yang diinisiasi sebagai bentuk diskriminatif gender. Hal itu dibuktikan dengan adanya subbab berjudul "Ajaran-Ajaran Fikih Diskriminatif" dan "Diskriminasi Jender dalam Ibadah Salat". Meski demikian telaah atas wahyu dalam Islam yang dilakukan oleh kamu liberal berkedok feminis tersebut bertujuan untuk melegalkan doktrin dan praktik turunan kesetaraan Jender seperti LGBT dan homoseksual. Mereka melabelkan bahwa usaha tersebut merukapan gerakan tajdid dalam Islam (Adian Husaini, 2020).

Oleh karena itu penulis melihat urgensi pemahaman konsep Islam dalam memandang gender dan kaum wanita sebagai upaya untuk mencegah pemikiranpemikiran kontemporer yang terpengaruh Barat dan jauh dari nilai-nilai Islam yang sebenarnya. 


\section{Metode Penelitian}

Untuk menjawab permasalahan yang telah dipaparkan dalam latar belakang sebelumnya, maka metode yang digunakkan oleh penulis dalam penelitian ini adalah metode kualitatif deskriptif. Hal ini sesuai dengan tujuan dari penggunaan metode kualitatif dalam penelitian adalah untuk menjelaskan mengenai pengertian suatu fenomena sosial, gejala, keadaan dan realita yang terjadi dan dibahas secara mendalam (Semiawan, 2010). Dalam penelitian ini akan dipaparkan mengenai perkembangan fenomena feminisme Islami. Pembahasan ini mencakup bagaimana pemikiran feminisme Barat mempengaruhi pemikiran Islam, kritik feminis Islami terhadap ayat Al-Qur'an, hadis misogini dan hukum-hukum Islam yang berkaitan tentang perempuan.

Adapun paradigma yang digunakan adalah paradigma kritis yang bertujuan untuk memberikan pemahaman baru yang melawan pemahaman sebelumnya (Manzilati, 2017). Penelitian ini mencoba menunjukkan bagaimana kajian Islam kontemporer menanggapi tuduhan-tuduhan feminis Islami dengan mengembalikan pada fakta-fakta dan bukti-bukti yang belum dibahas sebelumnya.

Data-data yang digunakan dalam penelitian ini berasal dari literatur-literatur baik buku, jurnal juga tulisan-tulisan yang membahas tentang feminisme dan Islam. Dengan demikian, penelitian ini dapat digolongkan menjadi studi pustaka dimana sumber data berasal dari buku, jurnal dan berbagai literatur yang berhubungan dengan penelitian (Cawelti, 1969).

\section{Hasil dan Pembahasan}

\section{A. Feminisme dan Barat}

Feminisme di Barat lahir dari kritik terhadap superioritas laki-laki dalam berbagai aspek kehidupan. Hal tersebut muncul akibat tradisi turun temurun yang merendahkan kaum perempuan. Adler menggambarkan betapa kejamnya pandangan dan perlakuan Barat terhadap perempuan. Di Eropa, hingga abad ke-17, wanita masih dianggap sebagai titisan setan atau alat setan untuk merayu umat manusia yang mungkin hal ini dipengaruhi oleh ide bahwa Eva yang tergoda oleh iblis kemudian ia menjerumuskan Adam. Dalam buku The Second Sex karya Simone de Beauvoir dipaparkan mengenai perlakuan dunia terhadap wanita di sepanjang sejarah. Dari tradisi dan kultur inilah menyebabkan gerakan feminisme mulai digaungkan sebagai upaya untuk meninggikan martabat kaum wanita (Adian Husaini, 2020).

Gerakan feminisme muncul pertama kali di Perancis dipelopori oleh pemikiran seorang aktivis sosialis yang bernama Charles Fourier pada tahun 1837 dengan gagasan transformasi perempuan di mayarakat yang berlandaskan asas saling ketergantungan dan kerjasama buka pada kompetisi dan mencari keuntungan. Pemikiran Charles ini lalu mempengaruhi berbagai pemikiran perempuan yang kemudian berkembang dari emansipasi pribadi menjadi emansipasi sosial (Rokhmansyah, 2016). Gerakan feminisme ini kemudian berkembang di Amerika menjadi feminis sosialis dan merambah kepada konsep gender pada tahun 1970. 
Pada 1977 muncullah wacana gender yang dipelopori kaum feminis di London yang kemudian menjadikan kesetaraan gender sebagai pokok gerakan mereka. Konstruksi sosial yang mereka usung berbeda dengan konsep sex yang merujuk kepada anatomi biologis. Menurut mereka, konsep kesetaraan gender ini dipengaruhi oleh kondisi sosial-budaya, agama dan hukum yang berlaku di masyarakat serta faktor lainnya. Sebagaimana yang dikutip oleh Alfian Rokhmansyah dari Lips bahwa gender tidak hanya dua, feminin dan maskulin, tetapi ada gender ketiga yang bersifat liquid dan dapat berubah yaitu kaum homoseksual dan transvestite (Rokhmansyah, 2016).

Feminisme yang muncul di Barat adalah sebuah gerakan yang menuntut emansipasi atau kesamaan dan keadilan hak dengan pria yang terdiri dari beberapa bagian sosial, budaya, pergerakan politik, ekonomi, teori-teori dan filosofi moral. Gerakan ini secara garis besar dikelompokkan menjadi tiga gelombang gerakan feminisme (Rokhmansyah, 2016):

1. Akibat revolusi Amerika dan Perancis muncullah gagasan persamaan hak antara wanita dan pria dalam kehidupan publik dan status legal dalam rumah tangga. Teori yang muncul pada gelombang ini adalah teori Feminisme Liberal, Feminisme Radikal, Feminisme Marxis/Sosialis

2. Gelombang kedua menekankan kesetaraan wanita dan pria secara politik dan hukum dengan puncak wanita mendapatkan hak memilih dalam parlemen. Teori gelombang kedua feminisme ini ditandai dengan munculnya Feminisme Psikoanalisis dan Feminisme Eksistensialisme

3. Keragaman perempuan dalam artian sebagai kritik terhadap hasil feminisme gelombang kedua yang membedakan perempuan kulit putih dan kulit hitam. Teori yang mucul adalah feminisme postmodern, feminisme multikultural dan global.

Barat pun yang merupakan tempat munculnya gerakan ini terkesan telah terlampau membebaskan gerakan wanita sebebas-bebasnya setelah memperlakukan wanita dengan sangat keji di masa lampau. Sehingga isu feminisme dan gender di Barat tidak ada habisnya untuk dibahas dan dikaji dan selalu mengalami perkembangan. Feminisme di Barat berjalan seiring dengan kemunculan pemikiran modern dan postmodern yang mengkritisi segala doktrin yang bersifat kaku.

\section{B. Feminisme dan Islam}

Gerakan feminisme dan gender yang mulai merambah ke dunia Islam akibat pengaruh Barat juga cukup menyita perhatian publik dengan konsep-konsep yang ingin merekonstruksi ulang tatanan hukum Islam beserta kajian al-Qur'an dan hadits yang terkesan menyudutkan wanita. Padahal perlu diingat bahwa Islam dan ajarannya juga telah memberikan perhatian terhadap martabat dan harakat wanita. Meski demikian pemikiran feminisme mengkritisi kajian Islam klasik yang dianggap patriarki.

Feminis muslim mulai muncul bersamaan dengan gelombang ke ketiga gerakan feminisme, yakni di tahun 1990-an. Fatima Seedat berpendapat bahwa feminisme dan Islam sebagai dua tradisi intelektual dapat bersatu dalam konsep 
feminisme Islami. Hal ini merupakan konvergensi antara Islam dan feminisme yang tidak berusaha mengikis perbedaan tetapi mempertahankan jarak keuda tradisi itu untuk lebih produktif. Oleh karena itu, menurut para feminis muslim, kajian Islam dan feminis sangat mungkin dilakukan. Karena keduanya memiliki tradisi keilmuan yang mampu berdialog satu dan lainnya (Fatima Seedat, 2012).

Para pejuang gender dari feminis muslim lebih fokus terhadaap dua pembahasan. Pertama, ketidaksetaraan antara laki-laki dan perempuan dalam struktur sosial masyarakat muslim tidak berakar pada ajaran Islam yang eksis, tetapi pada pemahaman bias laki-laki yang selanjutnya terkristalkan dan diyakini sebagai ajaran Islam yang baku. Kedua, dalam rangka bertujuan mencapai kesetaraan perlu pengkajian kembali terhadap sumber-sumber ajaran Islam yang berhubungan dengan relasi gender dengan bertolak dari prinsip dasar ajaran yaitu keadilan dan kesamaan derajat. Harapannya adalah terciptanya keadilan dan kerjasama antara laki-laki dan perempuan tidak hanya di tingkat makro tetapi juga di tingkat mikro (Muqoyyidin, 2013). Hal inilah yang kemudian menjadi latar belakang usaha feminis dalam mengkaji ulang tafsir Al-Qur'an ataupun hadits yang dianggap tidak lagi relevan dengan zaman sekarang (Muqoyyidin, 2013).

Salah seorang tokoh feminis yang mencoba untuk mengkaji al-Qur'an adalah Amina Wadud. Amina Wadud yang lahir di Amerika Serikat pada 1952 ini masuk Islam pada 1972. Ia menggunakan metode hermeneutik untuk menafsirkan ayat-ayat al-Qur'an dengan kacamata feminis dengan karya fenomenalnya Al-Qur'an dan Perempuan: Membaca Ulang teks Suci dari Women Perspektif. Ia berpendapat bahwa salah satu sebab adanya ketidak adilan gender dalam kehidupan adalah karena penafsiran al-Qur'an oleh ulama klasik dianggap mengusung bias patriarki. Padahal menurutnya prinsip dasar dan spirit al-Qur'an telah menempatkan laki-laki dan perempuan dengan sangat adil dimana keduanya memiliki hak dan kewajiban yang sama dalam semua bidang. Namun hal itu terdistorsi oleh tafsir yang patriarki dan diperkuat dengan keadaan politik dan sosial. Oleh karena itu untuk memperoleh tafsir yang objektif maka seorang mufassir harus merujuk kembali pada prinsipprinsip dasar al-Qur'an dalam paradigmanya. Sehingga Amina Wadud menekankan bahwa seorang mufassir haruslah memiliki worldview. Pembahasan Wadud tentang posisi perempuan dalam bukunya terkesan ringkas dan sederhana. Namun, dia menekankan semangat egalitarianisme dalam bukunya. Ia tidak menganggap matriarki sebagai pengganti patriarki, yang disalahkan pada status subordinat perempuan (Wadud, Ali, \& Abdullah, 2006).

Tidak hanya Amina Wadud, Fatima Mernissi juga mengkritisi hadist-hadits yang dianggap tidak adil bagi wanita. Fatima Mernissi merupakan tokoh feminis yang lahir di Maroko pada 1940 dan besar dalam tradisi pembatasan ruang gerak wanita di sebuah tempat yang disebut harem. Ia mengkaji ulang hadits misoginis dengan metode historis-sosiologis yang menelaah para perawi hadits tersebut. Pemkiran Fatima ini dipengaruhi oleh budaya saat ia belajar di Perancis yang mengusung konsep individualisme, liberalisme dan kebebasan individu yang 
berkembang di Barat. Dalam pembahasan mengenai hadis misoginis, Fatima mengkritisi konsep patriaki dalam penafsiran para ulama klasik. Menurutnya konsep persamaan antara laki-laki dan perempuan didasari atas nilai-nilai yang terkandung dalam nash, sedangkan marhinalisasi perempuan dalam kehidupan publik merupakan konstruksi sosial. Oleh karena itu kesetaraan gender memiliki arti kesamaan kondisi antara laki-laki dan perempuan untuk memperoleh kesempatan yang sama di berbagai aspek kehidupan seperti poitik, hukum, ekonomi, sosial, budaya, pendidikan dan lain sebagainya agar mampu ikut andil dan berperan di dalamnya. Maka Fatima menyatakan bahwa Islam memberikan kebebasan kepada perempuan untuk ikut terjun di dalamnya (Setiawan, 2019).

Ayat-ayat tentang waris merupakan respon terhadap kondisi sosial-historis masyarakat Arab saat itu. Perempuan adalah makhluk yang tidak memiliki hak kepemilikan atas harta, bahkan perempuan merupakan harta bagi laki-laki terdekatnya. Ia tidak berhak mewarisi bahkan mendapatkan warisan. Jika dilihat dalam kaca mata sosiologis, ayat-ayat waris menyadarkan masyarakat Arab bahwa perempuan bukanlah objek memainkan subjek sebagaimana laki-laki yang berhak mewarisi atau diwarisi sehingga pada ayat-ayat waris merupakan langkah awal sebagai upaya perbaikan posisi perempuan dalam masyarakat dan tentu perbaikan tidak boleh berhenti dan harus menyesuaikan ruang dan waktu dimana perbaikan itu dibutuhkan. Pembagian warisan dalam Islam tidak hanya berhenti pada kitab-kitab fiqh klasik saja, Diketahui bersama bahwa al-Qur'an adalah pasti dan mutlak namun penafsirannya bisa jadi keliru, artinya tidak dapat dijadikan hukum untuk ruang dan awaktu yang berbeda. Hukum Islam tentang waris yang turun temurun merupakan instruksional yang khusus pada hal-hal yang terjadi pada saat wahyu itu diturunkan (Sriani, 2018).

\section{Kritik Pemikiran Feminisme dalam Islam}

Untuk memahami bagaimana Islam memandang wanita, penulis akan memaparkan mengenai ayat al-Qur'an yang membahas wanita adalah surat An-Nisa ayat 1 yang berbunyi:

"Hai sekalian manusia, bertakwalah kepada Tuhan Kalian yang telah menciptakan kalian dari seorang diri, dan darinya Allah menciptakan istrinya; dan dari keduanya Allah memperkembang-biakkan laki-laki dan perempuan yang banyak. Dan bertakwalah. kepada Allah yang dengan (mempergunakan) nama-Nya kalian saling meminla satu sama lain, dan peliharalah hubungan silaturahmi. Sesungguhnya Allah selalu menjaga dan mengawasi kalian."

Dalam tafsir Ibnu Katsir, Allah memerintahkan manusia untuk bertaqwa kepada-Nya sebelum menjelaskan mengenai penciptaan manusia. Hal itu ditujukan untuk memahami bahwa manusia diciptakan dari nafsin wahidah yaitu Adam, dimana Hawa diciptakan pula dari tulang rusuk Adam bagian belakang yang sebelah kiri ketika Adam sedngan tidur. Ketika Adam bangun dari tidurnya, Adam dikejutkan dengan keberadaan Hawa, yang kemudian berlanjut menjadi ketertarikan satu dan lainnya. Hal tersebut sesuai dengan hadits riwayat Bukhori no. 3331 yang 
berbunyi: "Sesungguhnya wanita diciptakan dari tulang rusuk. Dan sungguh bagian yang paling bengkok dari tulang rusuk adalah yang paling atasnya. Bila engkau ingin meluruskannya, engkau akan mematahkannya. Dan jika engkau ingin bersenang-senang dengannya, engkau bisa bersenang-senang namun padanya ada kebengkokan (Ibnu Katsir, 2019).”

Tidak berbeda jauh dengan penafsiran Ibnu Katsir, salah seorang mufassir kontemporer, M. Quraisy Shihab berpendapat bahwa kalimat min nafsin wahidatin memiliki konteks yang sama dengan ayat 13 surat Al-Hujurat, yang berbicara mengenai asal kejadian manusia dari seorang ayah dan ibu. Tetapi penekanannya ada pada hakikat kemanusiaan setiap orang meski berbeda ayah dan ibu. Oleh karena itu tidak wajar apabila merendahkan manusia yang satu dan lainnya. Maka, memang isi dari surat An-Nisa ayat 1 ini menjelaskan mengenai persamaan hakikat kemanusiaan (M. Quraish Shihab, 2006).

Para feminis beranggapan bahwa tafsir yang mengartikan bahwa Hawa diciptakan dari tulang rusuk Adam merupakan alasan subordinasi perempuan. Namun, tidak ada pembiasan gender dalam Islam. Bias gender adalah kondisi yang memihak atau merugikan salah satu jenis kelamin. Dalam bias gender, terdapat pembagian posisi dan peran yang tidak adil antara laki-laki dan perempuan. Perempuan dengan sifat feminim dipandang selataknya berperan di sektor domestik, sebaliknya laki-laki yang maskulin sudah sepatutnya berperan di sektor publik. Artinya paham tafsir tersebut mendukung konsep bias gender ini (Rokhmansyah, 2016). Yang perlu dipahami dari ayat ini, adalah bahwa seluruh manusia memang berasal dari yang satu, min nafsin wahidah, sehingga menekankan kesamaan hakikat seluruh manusia baik yang laki-laki maupun perempuan. Namun beberapa penafsiran yang mengatakan bahwa Hawa diciptakan dari Adam masih menjadi perdebatan, karena penafsiran tersebut muncul dipengaruh oleh tafsir israiliyyat. Sedangkan dalam al-Qur'an itu sendiri tidak terdapat terminologi mendetail tentang hal tersebut (Yusuf, 2013).

Dalam hal ini, penulis melihat bahwa konteks kesamaan hakikat seluruh manusia memiliki korelasi dengan konsep bahwa tidak ada perbedaan derajat antara laki-laki dan perempuan. Tidak ada pihak yang mendominasi satu dan lainnya. Tidak ada superioritas laki-laki maupun subordinasi perempuan. Oleh karena itu, keinginan feminis untuk melebihi laki-laki tidaklah sesuai dengan konsep hakikat manusia itu sendiri. Sesuai dengan firman Allah bahwa yang membedakan manusia di mata Allah hanyalah ketaqwaan.

Berkaitan mengenai pembahasan sebelumnya, bahwa Hawa diciptakan dari tulang rusuk Adam, terdapat beberapa hadits Rasul yang dianggap misoginis atau membeci perempuan. Hal itu disampaikan oleh Riffat Hasan dalam kritiknya terhadap terhadap hadits tersebut dari segi sanad dan matannya. Riffat Hasan mengkritisi Abu Hurairah sebagai perawi hadits tersebut yang dianggap kontroversional, dan hadits tersebut merupakan hadits gharib, serta perawinya dianggap tidak tsiqoh sehingga hadist itu dinyatakan dhaif. Namun, tuduhan tersebut 
tidaklah benar, karena jika hadits diriwayatkan oleh perawi tunggal maka disebut hadits ahad bukan gharib. Dari segi matan yang menuduh hadits tersebut memiliki kesesuaian dengan injil dan bertentangan dengan al-Qur'an, juga dapat dijawab dengan kajian mufassir dalam surat An-Nisa ayat 1 mengenai penciptaan manusia. Arti min nafsin wahidah diartikan sebagai Adam, dhamir minha ditafsirkan sebagai bagian tubuh Adam dan zaujaha ditafsirkan sebagai Hawa. Sehingga ayat tersebut memiliki arti bahwa Adam dan Hawa diciptakan untuk saling melengkapi (Untung \& Idris, 2012).

Mengenai hadis misoginis yang dibahas oleh para feminis dan menitik beratkan kepada segi historis, ada beberapa hal yang perlu diperhatikan. Pertama, kajian hadis misoginis didasari oleh kajian orientalis terhadap beberapa hadis yang dilakukan oleh ulama klasik untuk mencari nilai dan hikmah dalam hadist Rasullullah SAW. Namun kajian kaum feminis didasari semangat kesetaraan gender yang berkembang di Barat dan mencoba untuk memasukkannya kedalam kajian hadist-hadits kontemporer sehingga menuai ketidaksesuaian makna dan maksud dari hadist Rasulullah sendiri (Untung \& Idris, 2012).

Dalam hal ini penulis melihat bahwa kajian feminis yang menilai bahwa hadits dipengaruhi oleh latar belakang perawi dan budaya patriarki tidaklah benar. Haditshadits Rasul memiliki kedudukan untuk memperjelas kandungan Al-Qur'an. Di dalamnya terdapat penjelasan-penjelasan yang membantu untuk mengerti kandungan yang terdapat dalam Al-Qur'an. Hal itu telah menjadi landasan para ulama terdahulu untuk mencoba menafsirkan ayat-ayat Al-Qur'an. Adapun penerimaan hadits dan pelabelannya bukan merupakan hal yang mudah. Banyak hal yang harus diperhatikan ketika akan melabeli hadits dengan sebutan shahih, hasan, dhaif dan lainnya, dilihat dari perspektif perawi, sanad dan matan. Lantas menuduh seorang perawi hadits berdasarkan suatu peristiwa yang dianggap cacat berarti telah menafikkah usaha dan ijtihad para ulama klasik terdahulu yang mencoba menyampaikan hadits-hadits Rasul agar dapat dipelajari hingga saat ini. Maka kajian hadits-hadits yang dianggap misoginis oleh para kaum feminis harus dilihat dengan kacamata yang shalih tanpa adanya corak pemikiran yang terpengaruh Barat.

Islam adalah agama yang sangat memperhatikan aspek "memanusiakan perempuan". Islam adalah agama visioner yang bertujuan mengarah pada pembentukan masyarakat yang adil. Namun sayangnya, ajaran Islam terkadang disalahpahami. Islam terkadang dianggap sebagai agama yang memiliki makna kekal dalam masyarakat, seolah-olah ini adalah jalan Tuhan yang tidak berubah. Menurut Zaitunah, dalam hal ini refactoring diperlukan untuk menyesuaikan diri dengan realitas yang lebih dinamis, yaitu realitas yang dapat menjadi salah satu landasan utama pemahaman teks-teks agama agar selalu kontekstual, tidak hanya bersifat historis. Dalam bahasa fiqh disebut shalihun li kulli zaman wa makan. Dalam konteks feminisme, perempuan seharusnya tidak lagi dianggap lemah, inferior, emosional, tidak pantas, tidak pantas, tidak beralasan, atau bahkan 
memfitnah. Oleh karena itu, perlu dipahami kembali konsep maqashid as-syariahsebagai bentuk tafsir fiqh (Sukron, 2009).

Dalam kajian fiqih, para penggiat isu feminisme dan gender mengkritisi mengenai patriarki laki-laki dan subordinasi perempuan. Salah satu isu yang diangkat adalah mengenai kepemimpinan dalam rumah tangga dan hak waris. Mereka mengkritisi penafsiran mufasir laki-laki dan menerpakan metode hermeneutika dalam menafsirkan al-Qur'an berkenaan dengan hal tersebut. Ayat mengenai kepemimpinan dianggap hanya sekedear kontekstual saja sehingga konteks domestik tidak hanya berlaku pada perempuan saja, namun juga laki-laki akibat adanya perubahan sosiologis nilai budaya dan kondisi yang juga berubah. Dalam hal waris para feminis juga melihat hal tersebut merupakan produk ijtihadi yang bersifat relatif, sehingga memungkinkan adanya perubahan berlatar sosial ekonomi keluarga (Apandi, 2015).

Dalam hal ini, penulis melihat adanya semangat perubahan yang digaungkan oleh para feminis dengan tujuan menaikkan martabat wanita. Namun semangat itu ditunggangi oleh kepentingan lain yang memberatkan salah satu pihak. Patriarki dan subordinasi dijadikan alasan untuk mengkritisi berbagai produk ulama klasik. Hal yang harus diperhatikan adalah ijtihad para ulama fiqh klasik telah melalui jalan panjang yang kemudian mendapatkan kesepakatan jumhur ulama. Artinya pembahasan yang telah dipersoalkan merupakan bentuk upaya untuk mendalami arti Islam sebagai jawaban pada setiap persoalan kehidupan, bukan mempersoalkan masalah-masalah hasil ijtihad yang dikambing hitamkan berdasarkan pengaruh Barat.

\section{Kesimpulan}

Feminisme yang memasuki kajian Islam merupakan akibat pengaruh budaya Barat. Konsep feminisme yang mengkritisi tafsir al-Qur'an, hadits dan kajian fiqih merupakan kesalahpahaman dalam mengerti beberapa konsep dalam Islam yang dirasa kurang adil bagi perempuan dan melihatnya dari kontekstual semata. Patriarki dan subordinasi serta semangat emansipasi mendasari pemikiran-pemikiran tersebut dalam upaya merekonstruksi hasil dan produk ulama klasik.

Islam memandang wanita dalam konsep hakikat memiliki kesamaan derajat dengan laki-laki. Tidak ada perbedaan derajat antara satu manusia dan lainnya karena yang membedakan hanyalah tingkat ketaqwaanya. Kajian hadits misoginis oleh para feminis yang mengkritisi perspektif sanad dan matan juga memiliki kekurangan karena proses klasifikasi hadits merupakan bentuk usaha memahami dan memperjelas kandungan Al-Qur'an. Demikian pula dalam ranah fiqih mengenai kepemimpinan dalam keluarga dan hak waris. Meski laki-laki dan wanita memiliki hakikat kemanusiaan yang sama, namun secara kodrati tetaplah berbeda. Sehingga produk tafsir, hadits dan fiqih yang dituduh oleh para feminis memiliki ketimpangan gender di dalamnya tidaklah benar. Karena sejatinya Islam merupakan agama yang mengangkat harakat dan martabat wanita, bukan sebaliknya, sehingga pemahaman mengenai hak- 
hak wanita dalam Islam membutuhkan kacamata yang jernih tanpa terpengaruh pemikiran Barat.

\section{BIBLIOGRAFI}

Adian Husaini. (2020). Jangan Kalah Sama Monyet: 101 Gagasan Pemandu Pikiran pada Era Kebohongan. Yogyakarta: Pro-U Media.

Apandi, Taufik. (2015). Kritik atas Pemahaman Kaum Feminis terhadap Otoritas Mufasir Laki-laki. Kalimah: Jurnal Studi Agama Dan Pemikiran Islam, 13(1), 122. Google Scholar

Cawelti, John G. (1969). The concept of formula in the study of popular literature. Journal of Popular Culture, 3(3), 381. Google Scholar

Fatima Seedat. (2012). Feminisme, Islam dan Islam Feminis, (ttp: t.p, t.t). 51.

Ibnu Katsir. (2019). Tafsir Ibnu Katsir (Terjemahan) (9th ed.). Jakarta: Pustaka Ibnu Katsir.

M. Quraish Shihab. (2006). Tafsir Al-Misbah (Vol. 2). Jakarta: Lentera Hati.

Manzilati, Asfi. (2017). Metodologi penelitian kualitatif: Paradigma, metode, dan aplikasi. Universitas Brawijaya Press. Google Scholar

Muqoyyidin, Andik Wahyun. (2013). Wacana Kesetaraan Gender: Pemikiran Islam Kontemporer tentang Gerakan Feminisme Islam. Al-Ulum, 13(2), 490-511. Google Scholar

Rokhmansyah, Alfian. (2016). Pengantar gender dan feminisme: Pemahaman awal kritik sastra feminisme. Yogyakarta: Garudhawaca. Google Scholar

Semiawan, Conny R. (2010). Metode penelitian kualitatif. Grasindo. Google Scholar

Setiawan, Eko. (2019). Studi Pemikiran Fatima Mernissi Tentang Kesetaraan Gender. Yinyang: Jurnal Studi Islam Gender Dan Anak, 14(2), 221-244. Google Scholar

Sriani, Endang. (2018). Fiqih Mawaris Kontemporer: Pembagian Waris Berkeadilan Gender. TAWAZUN: Journal of Sharia Economic Law, 1(2), 133-147. Google Scholar

Sukron, Ahmad. (2009). Islam dan feminisme (Perspektif rekonstruksi hukum Islam). Muwazah: Jurnal Kajian Gender, 1(2), 135-146. Google Scholar

Untung, Syamsul Hadi, \& Idris, Achmad. (2012). Telaah Kritis terhadap Hadis Misoginis. Kalimah: Jurnal Studi Agama Dan Pemikiran Islam, 11(1), 38-53. Google Scholar 
Dzakiyyah Fauziyah Rif'at, Nurwahidin

Wadud, Amina, Ali, Abdullah, \& Abdullah, Kurniawan. (2006). Quran menurut perempuan: membaca kembali kitab suci dengan semangat keadilan. Serambi Ilmu Semesta. Google Scholar

Yusuf, Muhammad. (2013). Penciptaan dan Hak Kepemimpinan Perempuan dalam AlQur'an. Jurnal Ushuluddin: Media Dialog Pemikiran Islam, 17(1), 32-47. Google Scholar

\section{Copyright holder:}

Dzakiyyah Fauziyah Rif'at, Nurwahidin (2022)

First publication right:

Syntax Literate: Jurnal Ilmiah Indonesia

This article is licensed under:

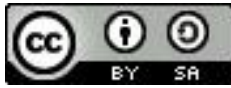

